Biol. Stud. 2010: 4(3); 81-88 • DOI: https://doi.org/10.30970/sbi.0403.152

www.http://publications.Inu.edu.ua/journals/index.php/biology

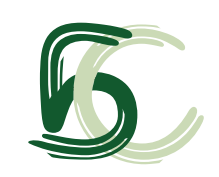

UDC 550.4

\title{
DISTRIBUTION OF HEAVY METALS IN THE PROFILE OF PEAT BOG ZHURAVLYNE (SKOLIVSKI BESKYDY, UKRAINIAN CARPATHIANS) AS AN INDICATOR OF CHANGES IN CHEMICAL COMPOSITION OF AIR PRECIPITATIONS IN HISTORICAL RETROSPECTIVE
}

\author{
V. Kozlovskyy', M. Skrypnikova ${ }^{2}$, O. Uspenskaya ${ }^{3}$, N. Romanyuk $^{4}$ \\ ${ }^{1} /$ nstitute of Ecology of the Carpathians of National Academy of Sciences of Ukraine \\ 4, Kozelnytska St., Lviv 79026, Ukraine; e-mail:vkozlovskyy@gmail.com \\ ${ }^{2}$ Dokuchaev Soil Science Institute of Russian Academy of Agricultural Sciences \\ 7, Pyzhevsky Lane, Moscow 109017, Russia; e-mail: scloser@yandex.com, \\ ${ }^{3}$ Vegetable Institute of Russian Academy of Agricultural Sciences \\ h.500, v.Verea, Ramenskii dist, Moscow region 140153, Russia; e-mail: usp_olga@yandex.ru \\ 4/van Franko National University of Lviv, 4, Hrushevskyi St., Lviv 79005, Ukraine \\ e-mail: biolog@franko.Iviv.ua
}

Vertical distribution of ash, $\mathrm{Pb}, \mathrm{Cd}, \mathrm{Zn}, \mathrm{Fe}, \mathrm{Mn}, \mathrm{Cu}, \mathrm{Al}, \mathrm{Ca}, \mathrm{Mg}$ in oligotrophic bog "Zhuravlyne” (Skolivski Beskydy, Ukrainian Carpathians) was investigated. Vertical cores were sampled in 2006 and dated by ${ }^{14} \mathrm{C}$ method. Distribution of ash in peat slices increased considerably closer to the bog surface. Reasonable agreement exists in the comparison between the ash distribution and measurements of Al and Fe concentrations, what point to a decisive influence of aluminosilicate material formed from the rocks weathering on ash deposits. Historical trends of heavy metals levels in peat based on the absolute concentrations or their ratio to Al are identical and concomitant with the history of industrial development of Western Europe.

Key words: ombrotrophic peat bogs, heavy metals, Ukrainian Carpathians.

\section{INTRODUCTION}

Ombrotrophic peat bogs as a good paleobotanical object due to their geochemical peculiarities of development, due their ability to capture trace elements from atmosphere and possibility to date peat layers, are widely used for the study and reconstruction of the past years geochemical background since the 90 s of last century [18]. Analysis of the chemical elements distribution in different layers of oligotrophic peat mires allow to determine 1) the natural intensity of atmospheric precipitation of chemical elements, 2) the influence of anthropogenic factors on the precipitation process, 3) the level of air pollution compared to the previous natural geochemical background.

Carpathian peatlands - an object located far from pollution sources, belongs to protected areas and minimally influenced by human at the present time. That is not typical for most of the remaining wetland ecosystems of populated and industrialized European coun- 
tries, where local sources of pollution have begun to act since the Roman Empire [16; 13]. Therefore such locations are useful for identifying regional background of the natural environment and its changes under the human activities for the present, and in retrospect.

Ukrainian Carpathians are in the zone of continental European climate influence, the main features of which are determined by the predominance of Atlantic and transformed continental air masses [1]. Number of days with western winds exceeds twothirds of the total number [9], that it is important for understanding the sources of formation of temporal trends of chemical elements in oligotrophic bogs in the region.

According to the geobotanical zoning of the Ukrainian Carpathians Zhuravlyne belongs to the area of spruce-fir-beech and fir-spruce-beech forests [6]. Modern vegetation is dominated by swamp cenoses of association Sphagnetum magellanici, which in the central part of the peat bog is presented in its purest form. The grass layer is dominated by Eriophorum vaginatum, Oxycoccus palustris, Drosera rotundifolia, Carex limosa, moss layer - Sphagnum magellanicum, Sphagnum angustifolium. Sporadically Picea abies and Betula pendula occurs [4].

The total depth of peat from the surface is below $8 \mathrm{~m}$ [11].

The original purpose of the project was to estimate the historical trends of chemical elements and ash in the Zhuravlyne peat bog.

\section{MATERIALS AND METHODS}

Oligotrophic cotton grass-sphagnum bog Zhuravlyne with area of 0.7 hectares is located in National Nature Park "Skolivski Beskydy” on the right side of the flow Kamenka (the right tributary of the River Opir), in the canyon of the lower part of the northwestern offshoots of the Kluch mountain at $567 \mathrm{~m}$ above sea level (49 ${ }^{\circ}{ }^{\prime} \mathrm{N}, 23^{\circ} 34^{\prime} \mathrm{E}$ ).

Vertical cores from central part of Zhuravlyne bog were sampled using Geller borer with the length of the working part $50 \mathrm{~cm}$ in June 2006. The samples were packed in polyethylene film and transported to the laboratory. In the laboratory, the cores were cut into $5 \mathrm{~cm}$ slices and dried at $40^{\circ} \mathrm{C}$.

From each core dried slices were analyzed for $\mathrm{Pb}, \mathrm{Cd}, \mathrm{Zn}, \mathrm{Fe}, \mathrm{Mn}, \mathrm{Cu}, \mathrm{Al}, \mathrm{Ca}$, and Mg. A sample of $0.5-1 \mathrm{~g}$ was incinerated in porcelain crucibles at $450^{\circ} \mathrm{C}$. The ash was digested with a mixture of $\mathrm{HNO}_{3}: \mathrm{H}_{2} \mathrm{SO}_{4}$ acids (1:1), heated to boiling on a stove and diluted with demineralized water to final acids concentration $-2 \%$. $\mathrm{Pb}, \mathrm{Cd}, \mathrm{Zn}, \mathrm{Fe}, \mathrm{Mn}, \mathrm{Cu}$ were determined by atomic absorption method in the propane-butane-air flame, $\mathrm{Al}$ - colorimetrically with aluminon [8], $\mathrm{Ca}$ and $\mathrm{Mg}$ - complexometrically with murexide and methylthymol blue [2]. The detection limit for $\mathrm{Pb}$ is $2 \mu \mathrm{g}$ per $\mathrm{g}, \mathrm{Cu}-0,2, \mathrm{Mn}-1, \mathrm{Zn}-0,2$, $\mathrm{Cd}-0,1, \mathrm{Fe}-1 \mu \mathrm{g}$ per $\mathrm{g}, \mathrm{Al}-2 \mu \mathrm{g}$ per $\mathrm{g}$, Ca and $\mathrm{Mg}-0,1 \mathrm{mg}$ per $\mathrm{g}$.

Dating performed with radiocarbon method.

\section{RESULTS AND DISCUSSION}

Modern plant communities of the bog, the biological residues composition of peat core (Table), low ash content and calcium/magnesium ratios (Figure) support an oligotrophic interpretation of the bog origin [5].

To identify historical trends of chemical elements in the atmosphere by their accumulation in the peat is important to know the biological composition of sediments. The homogeneous composition of biological residues in the peat vertical profile indicates that additional factors, such as climatic and biogeochemical conditions when the peat was formed, species composition of the peat-forming plants could not affect the process of elements concentration. This considerably simplifies the interpretation of obtained

ISSN 1996-4536 • Біологічні Студії / Studia Biologica • 2010 • Том 4/№3 • С. 81-88 
data. The composition of biological remains of Zhuravlyne peat bog core is more or less uniform from the surface to a depth of $3.5 \mathrm{~m}$ with the degree of decomposition gradually changing from 1 (decomposed) to 3 (very slightly decomposed) scores according to the von Post 10-point scale [12].
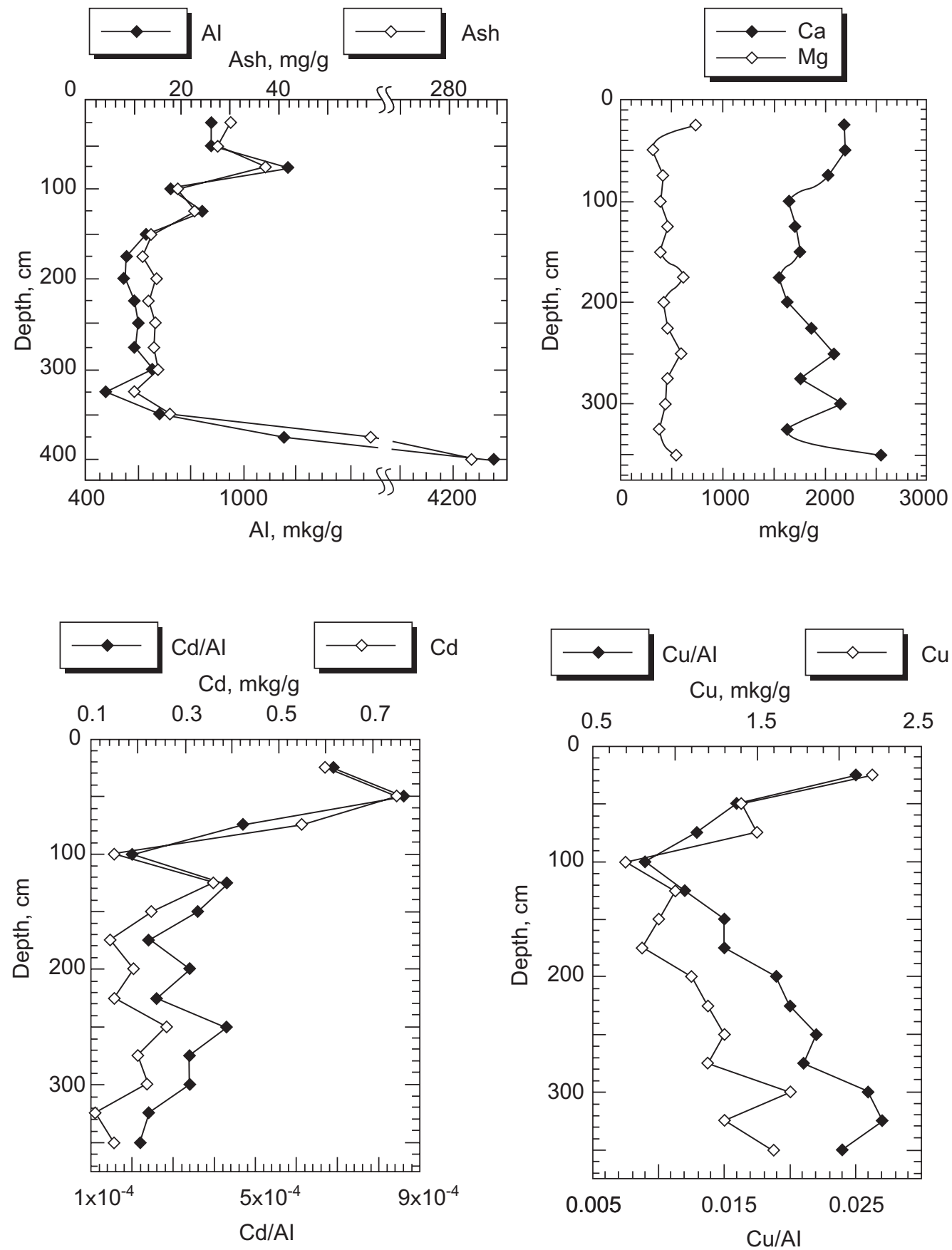

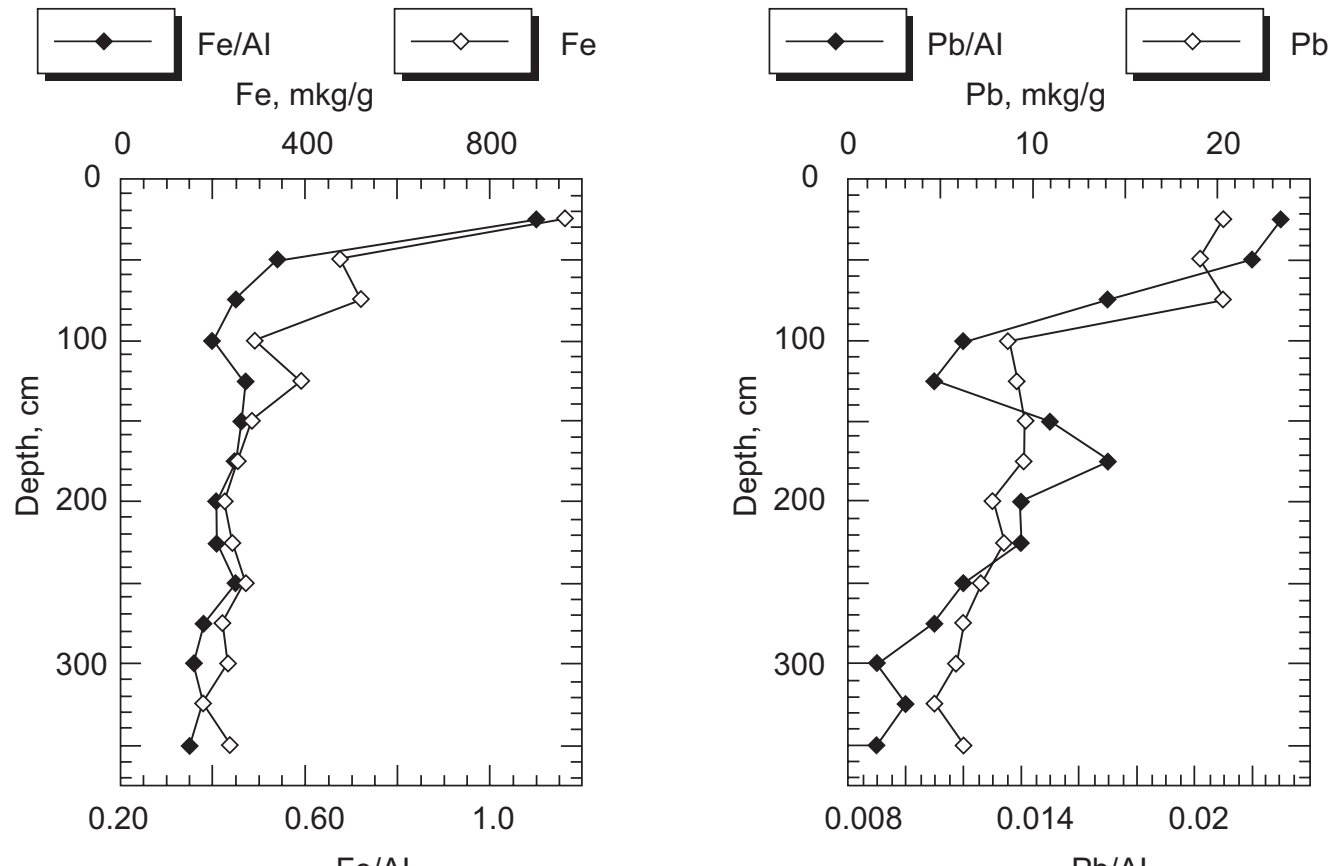

$\mathrm{Pb}, \mathrm{mkg} / \mathrm{g}$

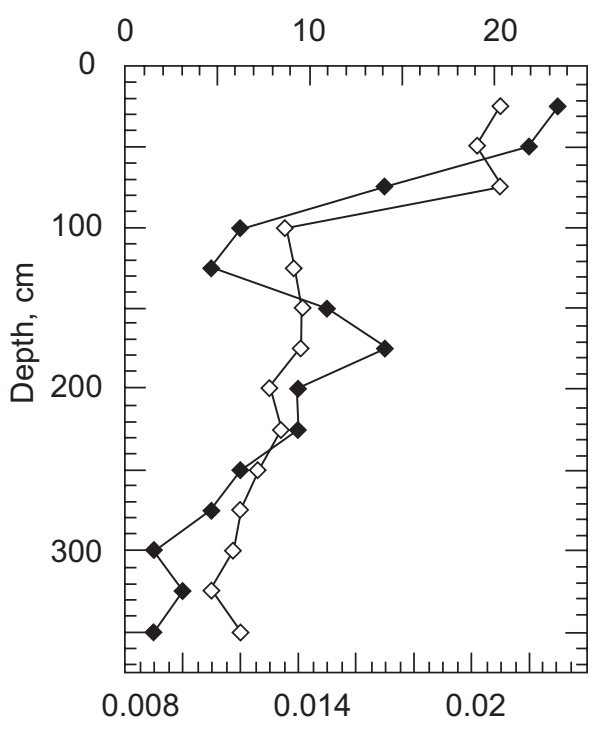

$\mathrm{Fe} / \mathrm{Al}$
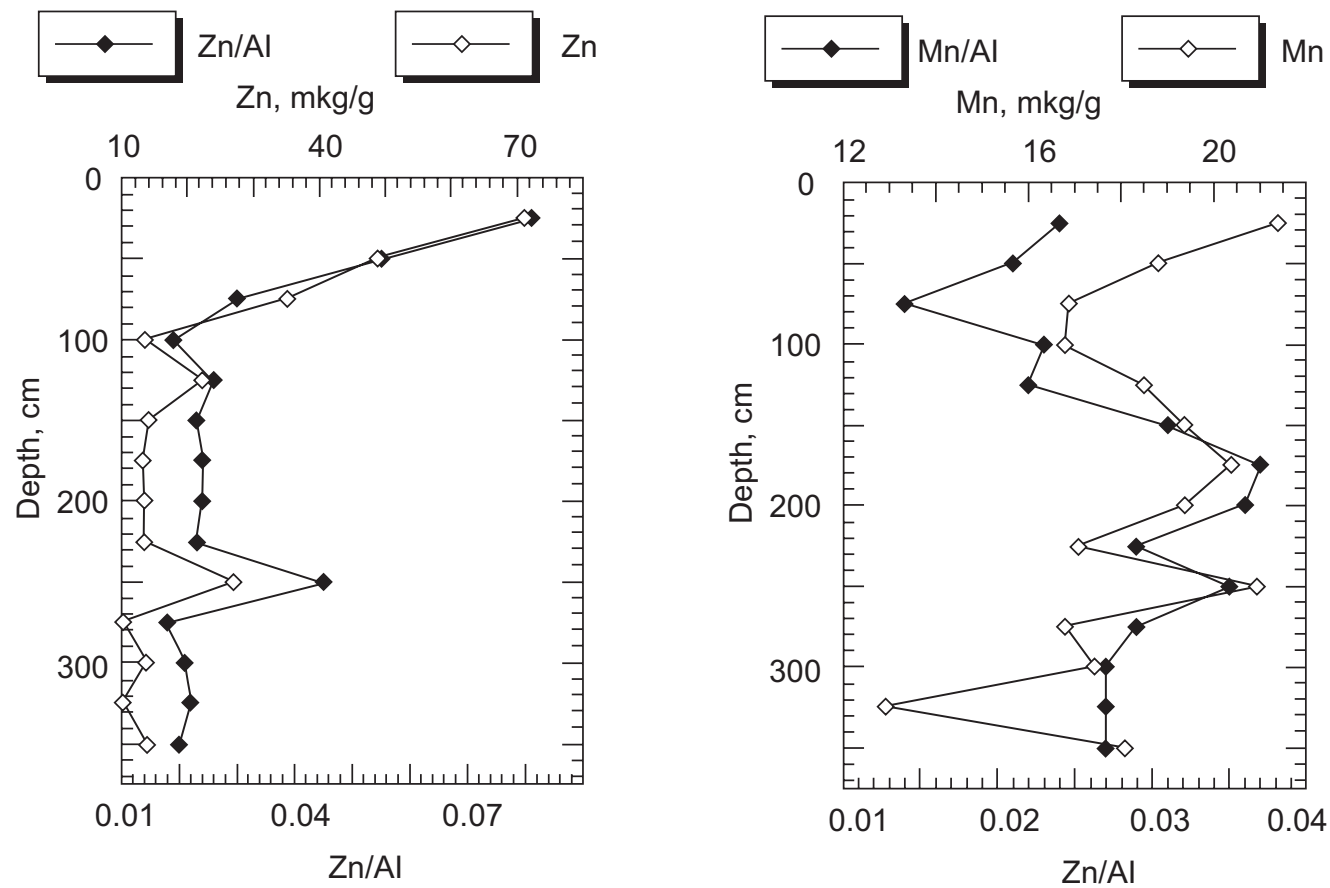

Concentrations of chemical elements and their evaluation according to $\mathrm{Al}$ in the profile ombrotrophic peat bog Zhuravlyne (Skolivski Beskydy, Ukrainian Carpathians, 11.07.2006)

Концентрація хімічних елементів і їхня нормалізація щодо Аl у профілі оліготрофного болота "Журавлине" (Сколівські Бескиди, Українські Карпати, 11.07.2006) 
Total biocomponents in deposits of the oligotrophic peat bog Zhuravlyne

(Skolivski Beskydy, Ukrainian Carpathians, 11.07.2006)

Груповий комплексний біосклад відкладів оліготрофного болота „Журавлине" (Сколівські Бескиди, Українські Карпати), 11.07.2006 р.

\begin{tabular}{|c|c|c|c|c|c|c|c|c|c|c|c|c|c|c|c|c|c|c|c|c|}
\hline \multirow{4}{*}{$\begin{array}{l}\frac{5}{0} \\
: \frac{0}{0} \\
\frac{0}{0} \\
\frac{0}{0} \\
\frac{0}{0} \\
\frac{\infty}{10} \\
\frac{1}{2}\end{array}$} & \multirow[b]{4}{*}{$\begin{array}{l}\frac{\varepsilon}{0} \\
\frac{5}{ \pm} \\
\frac{0}{1} \\
0\end{array}$} & \multicolumn{12}{|c|}{$\begin{array}{c}\text { Total biocomponents, } \% \text { to amount } \\
\text { of all residues }\end{array}$} & \multicolumn{7}{|c|}{$\begin{array}{l}\text { High plants, } \% \text { to sum of all } \\
\text { high plants residues }\end{array}$} \\
\hline & & \multirow[b]{3}{*}{ 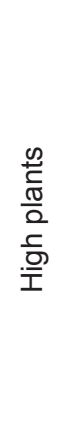 } & \multirow{3}{*}{ 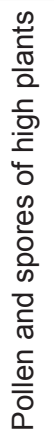 } & \multicolumn{4}{|c|}{ Animals } & \multicolumn{6}{|c|}{ Algae } & \multirow[b]{3}{*}{ 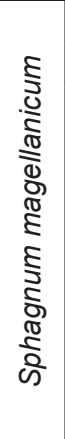 } & \multirow[b]{3}{*}{ 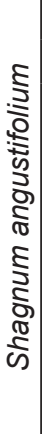 } & \multirow[b]{3}{*}{ 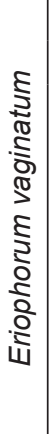 } & \multirow[b]{3}{*}{ 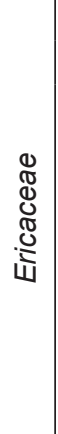 } & \multirow[b]{3}{*}{$\frac{\infty}{\frac{d}{d}}$} & \multirow[b]{3}{*}{$\frac{\times}{\mathbb{d}}$} & \multirow[b]{3}{*}{ 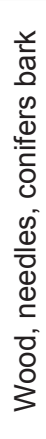 } \\
\hline & & & & & incl & $\mathrm{di}$ & $\mathrm{ng}$ & & & & & & & & & & & & & \\
\hline & & & & 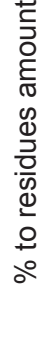 & $\begin{array}{l}\mathbb{0} \\
0 \\
N \\
0 \\
0 \\
0 \\
0\end{array}$ & 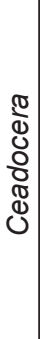 & 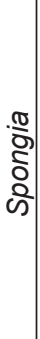 & 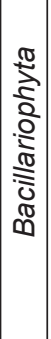 & $\left|\begin{array}{l}\frac{\pi}{2} \\
\frac{1}{\delta} \\
\frac{2}{0} \\
\frac{5}{2} \\
\frac{1}{0}\end{array}\right|$ & $\begin{array}{l}\frac{0}{1} \\
\frac{0}{0} \\
\frac{0}{0} \\
\frac{0}{0} \\
\frac{0}{0} \\
\frac{0}{0}\end{array}$ & 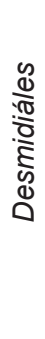 & 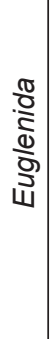 & 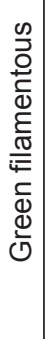 & & & & & & & \\
\hline & $5-25$ & 80 & $\mathrm{sp}$ & 20 & + & - & - & - & - & - & - & - & - & 95 & 5 & - & $\mathrm{sp}$ & - & - & - \\
\hline \multirow[t]{3}{*}{ 1920-1940 } & $25-50$ & 95 & $s p$ & 5 & + & - & - & - & - & - & - & - & - & 80 & 5 & 15 & $\mathrm{sp}$ & - & - & - \\
\hline & $50-75$ & 90 & $\mathrm{sp}$ & 10 & + & - & - & - & - & - & - & - & - & 95 & 5 & $\mathrm{sp}$ & - & - & - & - \\
\hline & $75-100$ & 90 & 5 & 5 & + & - & - & - & - & - & - & - & - & 90 & 5 & 5 & $\mathrm{sp}$ & - & - & - \\
\hline \multirow[t]{9}{*}{ 1820-1920 } & $100-125$ & 100 & $\mathrm{sp}$ & $c n$ & + & - & - & - & - & - & - & - & - & 95 & 5 & sp & $\mathrm{sp}$ & - & - & - \\
\hline & $125-150$ & 100 & $\mathrm{sp}$ & $\mathrm{sp}$ & + & - & - & - & - & - & - & - & - & 90 & 10 & $\mathrm{sp}$ & $\mathrm{sp}$ & - & - & - \\
\hline & $150-175$ & 100 & $s p$ & $\mathrm{sp}$ & + & - & - & - & - & - & - & - & - & 95 & $\mathrm{sp}$ & 5 & $s p$ & - & - & - \\
\hline & $175-200$ & 100 & $s p$ & $\mathrm{sp}$ & + & - & - & - & - & - & - & - & - & 90 & 10 & - & $\mathrm{sp}$ & - & - & - \\
\hline & 200-225 & 100 & $\mathrm{sp}$ & sp & + & - & - & - & - & - & - & - & - & 85 & 15 & $s p$ & - & - & - & - \\
\hline & $225-250$ & 100 & $\mathrm{sp}$ & $\mathrm{sp}$ & + & - & - & - & - & - & - & - & - & 80 & 20 & $\mathrm{sp}$ & $\mathrm{sp}$ & - & - & - \\
\hline & $250-275$ & 100 & $\mathrm{sp}$ & $\mathrm{sp}$ & + & - & - & - & - & - & - & - & - & 70 & 20 & 10 & $\mathrm{sp}$ & - & - & - \\
\hline & 275-300 & 100 & $s p$ & $\mathrm{sp}$ & + & - & - & - & - & - & - & - & - & 85 & 10 & 5 & - & - & - & - \\
\hline & $300-325$ & 100 & $\mathrm{sp}$ & $\mathrm{sp}$ & + & - & - & - & - & - & - & - & - & 95 & 5 & $\mathrm{sp}$ & - & - & - & - \\
\hline \multirow[t]{3}{*}{$980 \pm 50$} & $325-350$ & 100 & $\mathrm{sp}$ & $\mathrm{sp}$ & + & - & - & - & + & - & - & - & - & 85 & 15 & $\mathrm{sp}$ & - & - & - & - \\
\hline & $350-375$ & 45 & 5 & 5 & + & - & + & 40 & $\mathrm{sp}$ & 5 & $s p$ & $\mathrm{sp}$ & - & 30 & 50 & 20 & - & $s p$ & - & $\mathrm{sp}$ \\
\hline & $375-400$ & 30 & $\mathrm{sp}$ & $\mathrm{sp}$ & + & + & - & 65 & $\mathrm{sp}$ & 5 & - & $\mathrm{sp}$ & $\mathrm{sp}$ & 80 & 10 & 5 & $\mathrm{sp}$ & $\mathrm{sp}$ & $\mathrm{sp}$ & 5 \\
\hline
\end{tabular}

5-350 cm - typical upland sphagnum bog, no algae, only the simplest genera Amphitrema, Hyalosphenia, Webela etc. animals

$350-400 \mathrm{~cm}$ - shallow lake littoral habitats, algae $-45-70 \%$ of all residues, dominated by diatoms, typical of meso-and eutrophic waters

$\mathrm{sp}$ - occurs sporadically

The entire profile according to the content of chemical elements and ash can be divided into 2 parts: the sapropel (below 3,5 m) and the peat deposits, which was the subject of our study. Distribution of ash content in peat layers increases markedly closer to the surface from depth of $125 \mathrm{~cm}$. Changes in the ash content closely correlates with the aluminum content $\left(r^{2}=0,95, p=0,05\right)$, what indicate a decisive influence of alumina-silicate material formed during local rock weathering processes on the chemical content of the peat profile. The close links in the pairs Al-Fe $\left(r^{2}=0,77\right)$ and Fe-ash content $\left(r^{2}=0,92\right)$ can also be consequence of iron involvement in the ash formation by weathering. The fact of 
increasing of ash and aluminum contents could be associated with increased human activity in this region since the late XVIII-early XIX century (deforestation, agriculture) [7]. Concentrations of manganese, calcium, magnesium does not depend on the distribution of aluminum or ash, but there are elevated content in the upper layers. It occurs perhaps, due to biological processes (attraction of these elements to the surface by living plants) [10]. Increased concentrations of manganese and iron in the upper horizons can also be caused by a gradient of redox potential. $\mathrm{Mn}$ and $\mathrm{Fe}$, as the elements sensitive to this environmental parameter, are more mobile in the lower layers with lower potential and where therefore they are quickly washed out. Nevertheless, the small enrichment of the upper horizons with iron and manganese indicate their low mobility and, hence an even lower mobility of the other more geochemically inert elements. Especially it concerns lead, absorptive capacity of peat for which may reach $11 \%$ of the mass [3]. This suggests that the majority of lead and other heavy metals, falling on the marsh, are conserved in the thickness of the peat.

The highest concentration of other investigated elements is also confined to the upper layers of the peat. For $\mathrm{Cu}, \mathrm{Pb}, \mathrm{Cd}, \mathrm{Zn}$ it is $3-5$ fold higher compared with the lower horizons, where as for Fe, Mn, Ca, Mg, Al, it does not exceed 20-50\%. Absence or weak correlation between concentration of these elements and aluminum shows that the weathering products are not the main resource of their income on the surface of the swamp. Like the ash content, a sharp increase in the concentrations of $\mathrm{Cu}, \mathrm{Pb}, \mathrm{Cd}, \mathrm{Zn}$ starts with a depth of 125-150 cm, which corresponds to the first half-middle of the XIX century and is consistent with the history of industrial development in Western Europe. The first stage of this dramatic increase is related to an increase in the number of burned coal and increasing the volume of melted metal since 1850 and the second with the use of lead in gasoline in the period 1970-1990 [14].

The basis of upland bogs studies to reconstruct historical trends of chemical elements in the atmosphere is the ability of peat deposits record precipitation as it falls. However, the concentration of elements in the sediments is formed as the result of anthropogenic influence and as a result of rock weathering. To separate the natural component of human, not absolute concentration of elements, but their normalized values for the some lithophylic elemets (Al, Ti, Sc) are used [15,16,17,18]. Normalization of $\mathrm{Cu}, \mathrm{Pb}, \mathrm{Cd}, \mathrm{Zn}$ concentration to the content of aluminum does not differ from the distribution of heavy metals, identified on the basis of absolute concentration (Figure). Thus, we assume, that the enrichment of the upper peat layers with heavy metals is not due to changes in the amount of weathered deposits, but is a result of the long-distance transport of these elements.

\section{CONCLUSION}

A homogeneous composition of biological residues of oligotrophic cotton grasssphagnum bog Zhuravlyne (Ukrainian Carpathians) to a depth of $350 \mathrm{~cm}$, shows similar climatic conditions of formation of the peat thickness over $980 \pm 50$ years. The ash content increases toward the bog surface, ranging from $125 \mathrm{~cm}$ and closely correlates with the content of $\mathrm{Al}$ and $\mathrm{Fe}$ in the peat, which confirms the predominantly lithogenic nature of atmospheric deposits. The increase of ash content of peat layers corresponding to the end of the XVIII century can be a consequence of increased human activity (deforestation, agriculture) in the region. Temporal trends of $\mathrm{Pb}, \mathrm{Cd}, \mathrm{Zn}, \mathrm{Cu}$ in the upper part of the profile correspond to periods of industrial growth in Western Europe, beginning with the first half of the XIX century, which, in conditions of predominance for the Ukrainian Carpathian Mountains of western air mass, obviously, interrelated. The distribution

ISSN 1996-4536 • Біологічні Студії / Studia Biologica • 2010 • Том 4/№3 • С. 81-88 
of the other investigated elements is determined primarily by plant bioaccumulation processes (Mn, Ca, Mg) and (or) their geochemical properties of (Mn, Fe).

1. Алисов Б.П. Климат СССР. М: Изд-во МГУ, 1956. 157 с.

2. Аринушкина Е.В. Руководство по химическому анализу почв. Москва: Изд-во МГУ, 1970. 488 c.

3. Белькевич П.И., Чистова Л.Р. Торф и проблема защиты окружающей среды. Минск, 1979. $64 \mathrm{c}$.

4. Воронцов Д., Пука Є., Козловський В. Рослинний покрив оліготрофного пухівковосфрагнового болота „Журавлине” (НПП „Сколівські Бескиди”). Вісник Львів. у-ту. Сер. біол, 2004; 37: 114-125.

5. Геохимия озерно-болотного литогенеза. Под ред. акад. К.И. Лукашева. Москва: Наука и техника, 1971. 284 с.

6. Голубець М.А., Малиновський К.А. Рослинність. В кн.: Природа Українських Карпат. Львів: Вид-во Львів. ун-ту, 1968. С. 125-155.

7. Марискевич О.Г., Гнатів П.С. Історичні особливості Сколівського і Турківського районів. В кн.: Концептуальні засади сталого розвитку гірського регіону. Львів: Поллі, 2007. C. $50-61$.

8. Практикум по агрохимии. Под ред. В.Г. Минеева. Москва: Изд-во МГУ, 1989. 304 с.

9. Украинские Карпаты. Природа. Под ред. М.А. Голубца и др. Киев: Наукова думка, 1988. 208 c.

10. Görres M., FrenzelB. Ash and metal concentrations in peat bogs as indicators of anthropogenic activity. Water Air Soil Pollut, 1997; 100: 355-365.

11. Kalinovych N., Martynyak L. Pollen of synantropic plants in the late-Holocene deposits from the Eastern Beskyd region. Wczesne średniowiecze w Karpatach polskich. Krosno, 2006. S. 761-769.

12. McKeague J.A. Manual on soil sampling and methods of analysis. Second edition, Soil Research Institute, Agriculture Canada, Ont., 1978. 212 p.

13. Martínez C. A., García-Rodeja E., Pontevedra P. X. et al. Atmospheric Pb deposition in Spain during the last 4600 years recorded by two ombrotrophic peat bogs and implications for the use of peat as archive. The Science of the Total Environment, 2002; 292: 33-44.

14. Novak M., Erel Y., Zemanova L. et al. A comparison of lead pollution record in Sphagnum peat with known historical $\mathrm{Pb}$ emission rates in the British Isles and the Czech Republic. Atmospheric Environment, 2008; 42: 8997-9006.

15. Shotyk W. Natural and anthropogenic enrichments of arsenic through three Canadian ombrotrophic sphagnum bog profiles. In: Nriagu J. Arsenic in the Environment; Part 1: Cycling and Characterisation. New York: John Wiley and Sons Inc., 1994. P. 381-401.

16. Shotyk W., Cheburkin A., Appleby P. et al. Two thousand years of atmospheric arsenic,antimony and lead deposition recorded in an ombrotrophic peat bog profile, Jura Mountains, Switzerland. Earth Planet Sci Lett, 1996; 145: E1-E7.

17. Weiss D., Shotyk W., Cheburkin A.K. et al. Atmospheric lead deposition from 12400 to ca 2000 yrs BP in a peat bog profile, Jura Mountains, Switzerland. Water Air Soil Pollut, 1997; 100: 311-324.

18. Weiss D., Shotyk W., Appleby P.G. et al. Atmospheric Pb deposition since the Industrial Revolution recorded by five Swiss peat profiles: enrichment factors, fluxes, isotopic composition, and sources. Environmental Science \& Technology, 1999; 33: 1340-1352.

\section{РОЗПОДІЛ ВАЖКИХ МЕТАЛІВ У РОЗРІЗІ ВЕРХОВОГО ТОРФОВИЩА ЖУРАВЛИНЕ (СКОЛІВСЬКІ БЕСКИДИ, УКРАЇНСЬКІ КАРПАТИ) ЯК ПОКАЗНИК ЗМІНИ ХІМІЧНОГО СКЛАДУ АТМОСФЕРНИХ ОПАДІВ У ІСТОРИЧНІЙ РЕТРОСПЕКТИВІ}


В. І. Козловський ${ }^{1}$, М. І. Скрипнікова², О. Н. Успєнская ${ }^{3}$, Н. Д. Романюк

1/нститут екології Карпат НАН України, вул. Козельницька, 4, Львів 79026, Україна e-mail:vkozlovskyy@gmail.com

${ }^{2}$ Ґрунтовий інститут ім. В.В. Докучаєва РАСГН Пижевський перевулок, 7, Москва 109017, Росія 3/нститут овочівництва РАСГН Московськая обл., Раменський р-н, с. Верея, буд. 500, 140153, Росія ${ }^{4}$ Львівський національний університет імені Івана Франка вул. Грушевського, 4, Львів 79005, Україна

Досліджували вертикальний розподіл зольності, Pb, Cd, Zn, Fe, Mn, Cu, Al, Ca, Mg в оліготрофному болоті „Журавлине” (Сколівські Бескиди, Українські Карпати). Датування здійснено ${ }^{14} \mathrm{C}$ методом. Розподіл зольності за шарами торфу помітно збільшується ближче до поверхні й тісно корелює з вмістом Al та Fe, що свідчить про вирішальний вплив на формування зольності відкладень алюмосилікатного матеріалу, який утворився у процесі вивітрювання гірських порід. Історичні тренди вмісту важких металів у торфовищі, отримані на основі абсолютних концентрацій або після їхньої нормалізації щодо Al - ідентичні та добре узгоджуються з історією розвитку промисловості в Західній Європі.

Ключові слова: верхове торфовище, важкі метали, Українські Карпати.

\title{
РАСПРЕДЕЛЕНИЕ ТЯЖЕЛЫХ МЕТАЛЛОВ В РАЗРЕЗЕ ВЕРХОВОГО ТОРФЯНИКА „ЖУРАВЛЫНЭ” (СКОЛИВСКИЕ БЕСКИДЫ, УКРАИНСКИЕ КАРПАТЫ) КАК ПОКАЗАТЕЛЬ ИЗМЕНЕНИЯ ХИМИЧЕСКОГО СОСТАВА АТМОСФЕРНЫХ ОСАДКОВ В ИСТОРИЧЕСКОЙ РЕТРОСПЕКТИВЕ
}

\author{
В. И. Козловский', М. И. Скрыпникова ${ }^{2}$, О. Н. Успенская ${ }^{3}$, Н. Д. Романюк4 \\ ${ }^{1}$ Институт экологии Карпат НАН Украины, ул. Козельницкая, 4, Львов 79026, Украина \\ e-mail: vkozlovskyy@gmail.com \\ ${ }^{2}$ Почвенный институт им. В.В. Докучаева РАСХН \\ Пыжевский переулок, 7, Москва 109017, Россия \\ ${ }^{3}$ Институт овощеводства РАCXН \\ Московская обл., Раменский р-н, д.Верея, стр.500, 140153, Россия \\ ${ }^{4}$ Львовский национальный университет имени Ивана Франко \\ ул. Грушевского, 4, Львов 79005, Украина
}

Исследовали вертикальное распределение зольности, $\mathrm{Pb}, \mathrm{Cd}, \mathrm{Zn}, \mathrm{Fe}, \mathrm{Mn}$, $\mathrm{Cu}, \mathrm{Al}, \mathrm{Ca}, \mathrm{Mg}$ в олиготрофном болоте „Журавлынэ” (Сколивские Бескиды, Украинские Карпаты). Датирование производили С14 методом. Распределение зольности по слоям торфа заметно увеличивается ближе к поверхности и тесно коррелирует с содержанием $\mathrm{Al}$ и $\mathrm{Fe}$, что свидетельствует о решающем влиянии на зольность отложений алюмосиликатного материала, образовавшегося в процессе выветривания горных пород. Исторические тренды содержания тяжелых металлов в торфянике, полученные на основе абсолютных концентраций или после их нормализации относительно Al - идентичны и хорошо согласуются с историей развития промышленности в Западной Европе.

Ключевые слова: верховой торфяник, тяжелые металлы, Украинские Карпаты.

Одержано: 30.08.2010

ISSN 1996-4536 • Біологічні Студії / Studia Biologica • 2010 • Том 4/№3 • С. 81-88 